\title{
Articles
}

Central European Review of Economics \& Finance

Vol. 20, No. 4 (2017), pp. 49-59. Dol: 10.24136/ceref.2017.017

Ewelina Markowska ${ }^{1}$, Piotr Możyłowski

\section{ECONOMIC SITUATION AND MUNICIPAL BUDGET INCOME OF FORESTRY TAX}

The actual forestry tax is a relatively new development in the Polish tax system. It was introduced in 1991. It is one of the own revenues of municipalities. Budget revenues of municipalities in respect of forestry tax depend on the economic situation, as well as the degree of afforestation in the municipality. The aim of this publication is to present the economic impact on budget revenues of municipalities in respect of forestry tax.

JEL Classification Codes: H1, H2, N1.

Keywords: municipal budget, forestry tax, economic situation.

\section{Introduction}

Municipalities exist in the Polish legal system as the basic unit in the three stage division of local government (Gawrońska, 2009, p. 27), and they perform a wide range of its own and commissioned task. To accomplish their tasks an adequate level of funding is required. Both the Constitution and individual laws provide public funds to local governments, according to their tasks (Konstytucja RP z dnia 2 kwietnia 1997, art. 167). One of the most important sources of income of municipalities include taxes and local fees (see ustawa z dnia 12 stycznia 1991 r. o podatkach i opłatach lokalnych, ustawa $z$ dnia 15 listopada 1984 r. o podatku rolnym). Forestry tax belongs to the group of own revenues of municipalities and is qualified to own revenues of

\footnotetext{
${ }^{1}$ M.A., Ph.D. student, K. Pulaski University of Technology and Humanities in Radom, Poland, Faculty of Economic and Legal Sciences.

${ }^{2}$ Assistant Professor, Ph.D., Radom Academy of Economics.
} 
municipalities. Budget revenues from this tax allow municipalities to realize public tasks. The higher revenues, the more tasks municipality can realize. However, the budget revenues of municipalities in respect of forestry tax depend lastly on the economic situation as well as the degree of forestation in the municipality. This paper presents the revenues of municipalities in respect of forestry tax. The purpose of the authors was to present the economic impact on budget revenues of municipalities by the forestry tax over the past few years which has small significance for the fiscal budgets of local government.

\section{The economic cycle}

All market economies are subject to economic cycles. Occurring cycles can be observed both in the developed as well as in developing countries. The economic cycle is associated with certain disorders which are varying to the scale and time of occurrence(Hall, Taylor, 2000, p. 23). They interact with different strength as well as a different delay on the economy. Globalization and the increasing interdependence between the systems are the factors which consequently result in greater transmission of disorders between the economies. Today in the literature, concerning the economic situation, there are many variations and interpretations resulting from the formation of economic cycles. The most common economic cycle is defined as repeated but not always regular, in terms of duration and amplitude, fluctuations of economic activity. In terms of classic the cyclical fluctuations consist of four successive phases: flowering, slow down (the crisis), the recession and the recovery (Kalinowska, 2016, p. 101-102). The figure 1 shows the phases of the economic cycle.

The flowering phase is the end in which the Gross Domestic Product (GDP), consumption, investment and prices reach the highest level. The unemployment rate is at a relatively low level. On the other hand the slowdown phase is described by the overproduction and therefore advantage of supply in comparison with the effective demand. This results with the decrease in the business volumes, but the rate of decline of certain quantities is different. During the recession phase the unemployment is increasing and decreasing as follows: production, employment, investment and demand. The last discussed phase is the phase of recovery, which is defined as a period of gradual growth in GDP, consumption, investment, employment and prices (Kalinowska, 2016, p. 101-102). 


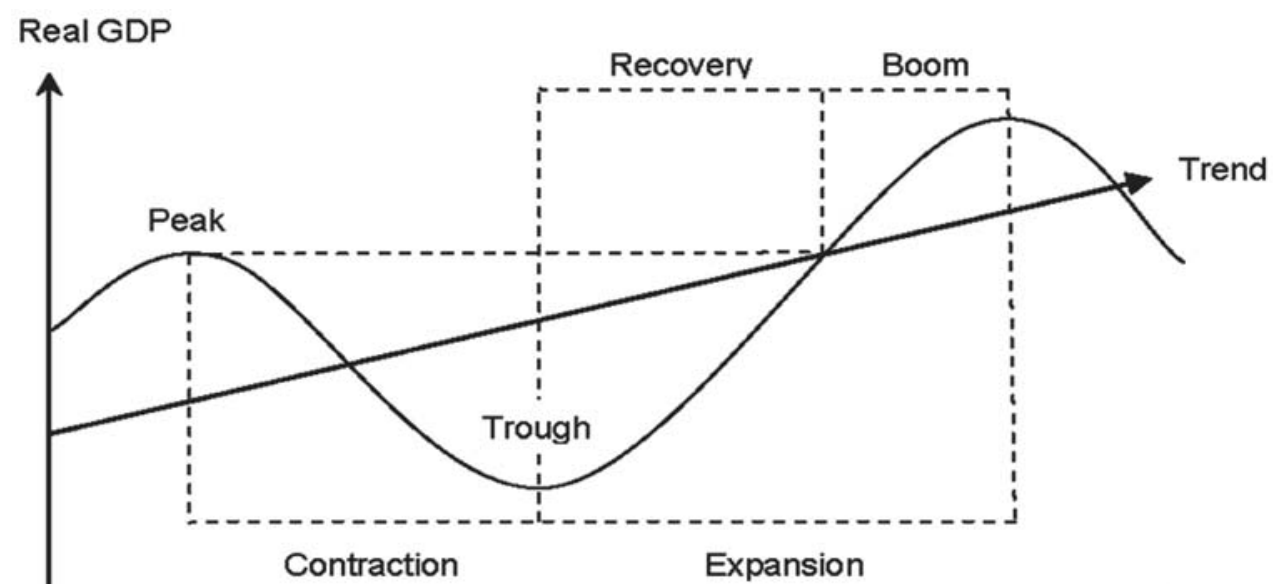

Time

Figure 1. Phases of the economic cycle

Source: http://financialplanningandretirement.com/w/index.php?title=Business_cycles [Access: 20.11.2016].

More and more frequently the economic literature describes two phases of economic cycle instead of four mentioned above. Those two phases are: downward and growth. The downward combines phase of the crisis and the lag phase, the phase of growth combines recovery and prosperity (Kalinowska, 2016, p. 101-102).

The recent economic crisis was begun by the situation in the US economy and which was then transformed into a global economic crisis. Economies of many countries, including Polish, have entered then in a very difficult period for the transition. Because of the recession mostly affected were the public finances. Because of the deteriorating economic situation at that time the basic unit of local government, which is the municipality, was obliged to take appropriate measures to improve the financial income (Antkiewicz, Pronobis, 2005, p. 54).

Current economic cycles that occur in market economies tend to the growing synchronization. This means the simultaneous occurrence of turning points and phases of the cycle. Institutional changes in the global economy, which include the liberalization of international flows of goods and money, the system of exchange rates, as well as similar economic policies actually decide on increasing compliance between countries (Kalinowska, 2016, p. 107). 
Present economic cycle is affected by a so-called flattening and therefore the amplitude of fluctuation is relatively small. Although the duration of the growth phase has been extended considerably while the low growth is reduced. In addition the amplitude of the whole cycle is positive (IMF, 2007, p. 67).

\section{Theoretical aspects of the forestry tax}

The actual forestry tax should be regarded as a relatively new structure in the Polish tax system. It was introduced to the Polish tax system with changes in 1991 by means of the law on forests (see Ustawa z dnia 28 września 1991 r. o lasach).

A primary construction of the forestry tax underwent substantial evolution over time. Undoubtedly this was related to the need to implement changes in it. They were associated with both the overvaluation of the philosophy of the use of forests as well as the emergence of significant hazards which are eligible like illegal acquisition and wood trading, the lack of management plans of forests. Moreover the neglect of renewal and negative impact of weather conditions were the factors of conditions of Polish forests (http://daniny.wro24.com.pl/index.php/41-system-podatkowy-w-polsce/ podatki/30-podatek-lesny).

The forestry tax is currently regulated by the Law on Forestry Tax stated on $30^{\text {th }}$ October 2002 (see Ustawa z dnia 30 października 2002 roku o podatku leśnym). The law introduces the definition of forest and forestry activities. The Law states that the forest lands are classified in the register of land and buildings as forests. On the other hand the forestry activities, within the meaning of this Law, are owners or managers of forests in the area of forest protection, management, maintenance and expansion of resources, as well as forest plantations and acquisition of - with the exception of purchase -wood, trees, stumps, bark, pine needles, animals and crops together with sale of these products in its raw state (Ustawa z dnia 30 października 2002 roku o podatku leśnym, Art. 1).

The taxpayers are individuals, legal persons and organizations, including companies and unincorporated, who are: forest owners and possessors of forests which are owned by the State Treasury or local government state (Ustawa z dnia 30 października 2002 roku o podatku leśnym, Art. 2).

The forestry tax obligation of forests that remain the State Forests National Forest Holding ownership (called "State Forests") and belonging to the Agricultural Property of the State Treasury with no obligation to pay tax, belongs the organizational units of the Agricultural Property Agency and the "State 
Forests". On the other hand, in the case when the forest is owned by spontaneous, then the tax liability belongs to the holder. However, if a forest is co-owned or it is in possession of two or more entities, the forestry tax must be paid by all co-owners or holders state (Ustawa z dnia 30 października 2002 roku o podatku leśnym, Art. 2).

The evolution of the Forest Law, and since 2002 the Law on Forestry Tax as well, primarily aimed to replace the rule of permanent professional production of wood with the principle of the greatest profitability - the principle of forest management covering the entire ecosystem and not just the stands. In this situation it has become necessary to take a legal protection of all forests regardless of the ownership (http://daniny.wro24.com.pl/index.php/ 41-system-podatkowy-w-polsce/podatki/30-podatek-lesny).

The basis of forestry tax taxation is a forest area, expressed in hectares, resulting from the register of land and buildings (Etel, 2009, p. 75). The forestry tax of 1 ha, for a certain tax year calculated from the cash equivalent of 0.220 cubic meter of wood. The price is calculated from the average price of wood obtained by the forest inspectorate in the first three quarters of the year preceding the tax year. For the forests included in nature reserves and national parks forestry tax rate is reduced by $50 \%$. The average selling price is determined by the state of the President of the Central Statistical Office, which is published in the Official Journal of the Republic of Poland „Polish Monitor", within 20 days after the end of the third quarter. Additionally the council of a municipality has the opportunity, by means of its resolution, reduce the amount representing the average selling price of wood as a basis for forestry tax calculation in the area of the municipality (http://www. finanse.mf.gov.pl/podatki-i-oplaty-lokalne/podatek-lesny).

Exemptions from the forestry tax are (ustawa z dnia 30 października 2002 roku o podatku leśnym, Art. 7 ):

a) forest with trees at the age up to 40 years,

b) forests individually registered in the register of monuments,

c) ecological areas,

d) higher education institutions, colleges and military high schools,

e) public and private schools, institutions, training institutions, teacher training centers and the authorities conducting these schools,

f) Polish Academy of Sciences,

g) conducting workshops for the disabled in the area of forest mentioned in the decision to grant the status of a protected work with the exception of forests that are held by subsidiaries of non conducting a workshop,

h) research and development centers. 
The tax liability of forestry tax arises on the first day of the month following the month in which the obligation was established. From the other hand the tax liability expires at the last day of the month in which the obligation is ceased. However, if the tax obligation arose or expired during the tax year, the forestry tax for the year is determined in proportion to the number of months in which there was an obligation. The tax authority competent in matters of forestry tax is the mayor (mayor, president of the city) (ustawa z dnia 30 października 2002 roku o podatku leśnym, Art. 5-6).

Forestry tax for the tax year from individuals is made by decision of the tax authority with jurisdiction over the forest location. This tax is payable in installments proportional to the duration of the tax obligation, in terms of 15 March, 15 May, 15 September and 15 November of certain fiscal year. When the tax obligation expires during the fiscal year or changes in the law occurs the tax authority changes its decision of establishing the tax. On contrary the organizations, including companies and unincorporated units of the State Forests, as well as the organization units of the Agricultural Property Agency of the Treasury are obliged to (ustawa z dnia 30 października 2002 roku o podatku leśnym, Art. 6):

a) submit, not later than 15 January, to the tax authority right to its location of forests, declarations of forestry tax drawn up on the form, and if the tax obligation arose after that date - within 14 days from the date of occurrence of this obligation,

b) adjust the declaration, if changes referred to in art. 5 paragraph. 4 occurs, within 14 days from the date when these changes are applicable,

c) pay money in installments, proportional to the duration of the tax, to the account of the budget of the relevant municipality, for each month not later than 15th day of month.

Forestry tax payment is possible by bank transfer or - in the case of individuals - cash - if the collection of the tax is made by the mayor for example. For individuals the forest tax is collected along with the agricultural tax and property tax as the total monetary obligation that is delivered in the form of a demand for payment (Rozporządzenie Ministra Finansów z dnia 21 grudnia 1999 r. w sprawie łącznego zobowiązania pieniężnego).

\section{Budget revenues of municipalities in respect of the forestry tax}

Before the data on budget revenues of municipalities in respect of the forestry tax will be presented we should refer to the economic situation in Polish 
economy. The basic indicator showing the economic situation in country is the Gross Domestic Product. The condition of the Polish economy between the years $2005-2015$ is presented by the following statistics.

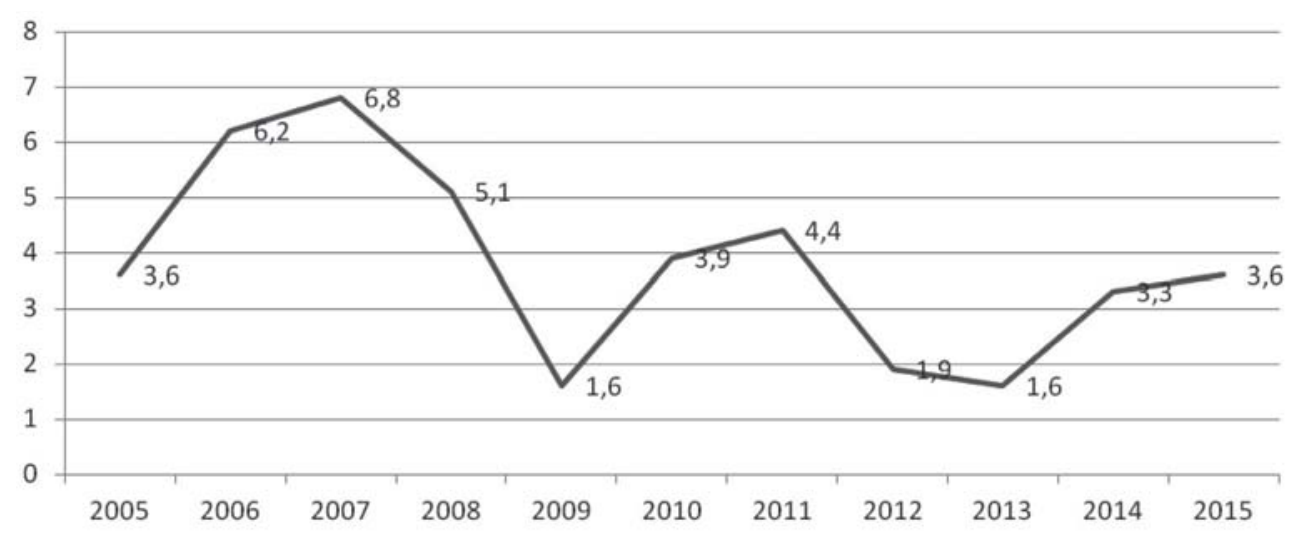

Figure 2. Evolution of Polish GDP between 2005-2015

Source: Self study on basis of: Roczne wskaźniki makroekonomiczne, Główny Urząd Statystyczny, http://stat.gov.pl/wskazniki-makroekonomiczne/ [access 20.06.2016].

Based on the above data it should be stated that in the years 2005-2007 Polish GDP has grown. As indicated by the chart since 2007 the downward trend of GDP is visible, which means that the Polish economy felt the impact of the global economic crisis. In 2009 it recorded weak growth of GDP when its growth rate in comparison to the previous year dropped by 3.5 percentage points. This is a significant decline in GDP growth, although GDP growth in Poland was visible, but it was a very slow rise. Following an increase in GDP growth observed during years 2010-2011, in 2012 Poland felt the economic slowdown resulting from the global economic crisis. From 2013 again the growth of Polish GDP is visible. The state of the economic situation affects the country as a consequence of public finances.

Long-term economic slowdown in Poland in year 2008-2009 was mainly affected the local government units and its own revenues, regardless of the tax system that feed the local budgets. In the case of municipal budgets the tax revenues differently react to the economic slowdown (Sońta, 2013, p. 26).

The forestry tax is an income of municipal budgets. The income from the budget enable the municipalities to realize public tasks. The following table shows the value of income to budgets of municipalities in respect of forestry tax in the period considered. 
Table 1. Number of the for estry tax In years 2006 - 2015 (in thousands PLN)

\begin{tabular}{|c|c|c|c|c|c|c|c|c|c|c|}
\hline Year & 2006 & 2007 & 2008 & 2009 & 2010 & 2011 & 2012 & 2013 & 2014 & 2015 \\
\hline $\begin{array}{c}\text { Forestry } \\
\text { tax }\end{array}$ & 150214 & 155708 & 173374 & 181011 & 163747 & 186051 & 224406 & 225461 & 207207 & 226822 \\
\hline
\end{tabular}

Source: Self-study on basis of http://www.finanse.mf.gov.pl/budzet-panstwa/finanse-samorzadow/opracowania [access 03.07.2016].

Based on the above data it should be noted that municipalities' budget revenues of from the forestry tax are growing in the years 2006-2009. In 2010 it is visible their decline, which could have a relationship with the economic slowdown that took place in Poland. Since 2011 again growth is visible. Only in 2014 decline is observed. In 2006 budget revenues from the tax were 150214 thousand PLN and in 2015 it have risen to 226822 thousand PLN.

The considerations above are graphically shows at figure 3 .

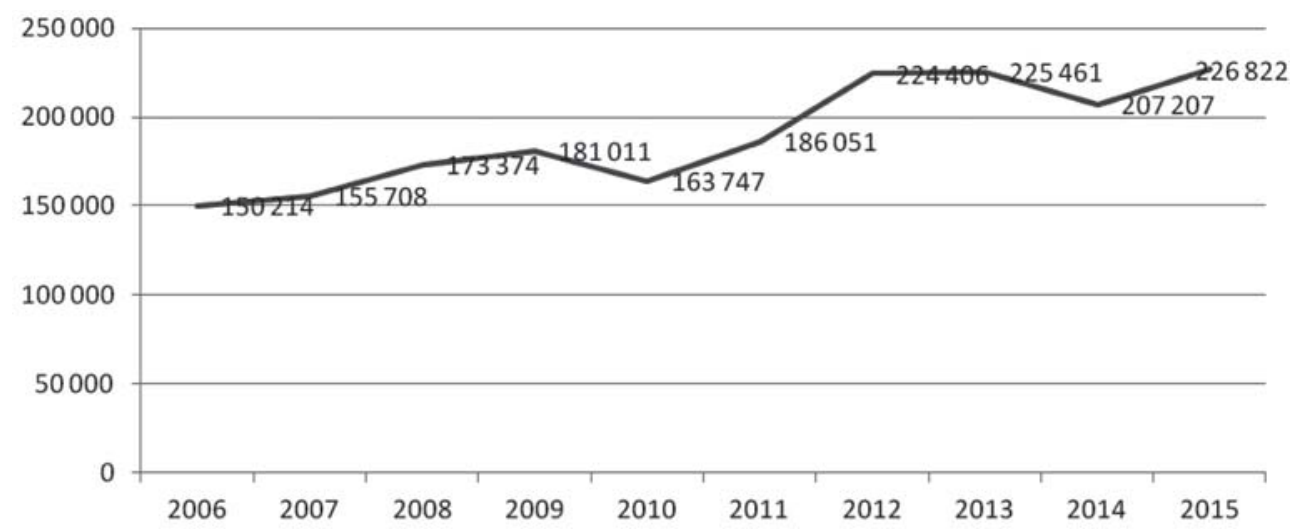

Figure 3. The forestry tax Mount In years 2006-2015 (in thousand PLN)

Source: self-study on basis of Graph 1.

Budget revenues of municipalities from the forestry tax had an upward trend. Their dynamic growth was observed in the years 2011-2013. In contrast, a significant decrease in revenues from this source was recorded in 2010 and 2014.

Table 2. The for estry tax dynamic in years 2007-2015 (in \%)

\begin{tabular}{|c|c|c|c|c|c|c|c|c|c|}
\hline Year & $\mathbf{2 0 0 7}$ & $\mathbf{2 0 0 8}$ & $\mathbf{2 0 0 9}$ & $\mathbf{2 0 1 0}$ & $\mathbf{2 0 1 1}$ & $\mathbf{2 0 1 2}$ & $\mathbf{2 0 1 3}$ & $\mathbf{2 0 1 4}$ & $\mathbf{2 0 1 5}$ \\
\hline Forestry tax & 104 & 111 & 105 & 91 & 113 & 120 & 101 & 92 & 109 \\
\hline
\end{tabular}

Source: self study on basis of Table 1. 
On the basis of the data in the table above it is clear that the budget revenues of municipalities from the forestry tax in 2008 compared to previous year increased by 11\%. In contrast their largest increase took place in 2012 compared to the previous year and was 20\%. In 2010 a decrease of revenues from this tax was noted in comparison to 2009 by $9 \%$. From the other hand in the 2014 a decrease in revenues was visible as well, in relation to 2013 , by $8 \%$.

Extremely important is the participation of the forestry tax in municipalities budget revenues. But also important is to show the development of their own revenues in the analyzed period, as shown in the chart below.

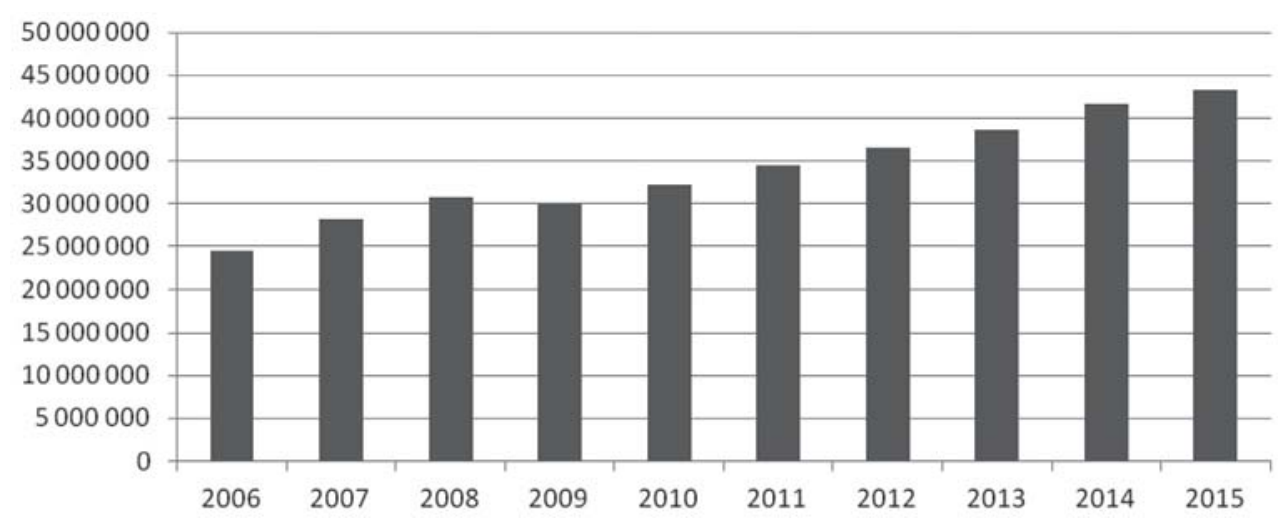

Figure 4. Municipal revenues in years 2006-2015 (in thousand PLN)

Source: self-study on basis of http://www.finanse.mf.gov.pl/budzet-panstwa/finanse-samorzadow/opracowania [access 03.07.2016].

Municipal revenues in analyzed period increased steadily. Only in 2009 it is visible their decline which was related to the economic slowdown that took place in Poland. The fact that the municipal revenues growth is positive because the disposal of the municipality can be spend on a statutory public tasks.

Table 3. The share of the forestry tax income of municipalities in years 2006-2015 (in \%)

\begin{tabular}{|c|c|c|c|c|c|c|c|c|c|c|}
\hline Year & 2006 & 2007 & 2008 & 2009 & 2010 & 2011 & 2012 & 2013 & 2014 & 2015 \\
\hline Share & 0.6 & 0.6 & 0.6 & 0.6 & 0.5 & 0.5 & 0.6 & 0.6 & 0.5 & 0.5 \\
\hline
\end{tabular}

Source: self study on basis of http://www.finanse.mf.gov.pl/budzet-panstwa/finanse-samorzadow/opracowania [access 03.07.2016]. 
The share of the forestry tax income of municipalities in the analyzed period is varying from $0.5 \%$ to $0.6 \%$. This is not a high proportion but plays an essential role in financing public tasks that must accomplished by a certain municipality.

\section{Summary}

The importance of the forestry tax to the budget of a municipality depends not only on the level of forestation but also on the state of the economy. During the global economic crisis that erupted in the United States, Poland suffered from its negative consequences. In general, as shown by statistics, revenues from that tax are only a small fraction of total income. However it should be kept in mind that municipalities have a wide spectrum of tasks that are required to implement and therefore budget revenues from the forestry tax are an important source of their income.

\section{References}

Antkiewicz S., Pronobis M. (2005). Gospodarka w warunkach kryzysu. Warszawa 2005.

Etel L. (2009). Konstrukcja prawna podatków i opłaty realizowane przez gminne organy podatkowe. Popławski M. (ed.), Wymiar i pobór podatków i opłat lokalnych. Temida 2. Białystok.

Gawrońska K. (2009). Podatki i opłaty lokalne w dochodach gminy. Popławski M. (ed.), Wymiar i pobór podatków i opłat lokalnych. Temida 2. Białystok.

Hall R., Taylor J. (2000). Makroekonomia. Warszawa PWN.

http://daniny.wro24.com.pl/index.php/41-system-podatkowy-w-polsce/podatki/30-podatek-lesny (Accessed: 20.11.2016 r.)

http://financialplanningandretirement.com/w/index.php?title=Business_cycles (accessed 20.11.2016).

http://www.finanse.mf.gov.pl/podatki-i-oplaty-lokalne/podatek-lesny (Accessed 29.11.2016 r.)

IMF (2007). The Chaging Dynamics of the Global Business Cycle.

Kalinowska K. (2016). Ujęcie teoretyczny empiryczne wzrostu i rozwoju gospodarczego. Kosztowniak A., Sobol M. (ed.), Współczesna Polityka Gospodarcza. Warszawa. CeDeWu.

Konstytucja RP z dnia 2 kwietnia 1997 (Dz. U. nr 78, poz. 483). 
Rozporządzenie Ministra Finansów z dnia 21 grudnia 1999 r. w sprawie łącznego zobowiązania pieniężnego(Dz. U. z 1999 r. nr 105, poz. 1200).

Sońta W. (2013). Przegląd podatków lokalnych i finansów samorządowych: Wpływ spowolnienia gospodarczego na dochody własne miasta Radomia, no. 5.

Ustawa z dnia 13 listopada 2003 r. o dochodach jednostek samorządu terytorialnego (Dz. U. z 2016, poz. 198).

Ustawa z dnia 28 września 1991 r. o lasach (Dz. U z 2016 r. poz. 422).

Ustawa z dnia 30 października 2002 roku o podatku leśnym (Dz. U. z 2015 r. poz. 1045).

Ustawa z dnia 12 stycznia 1991 r. o podatkach i opłatach lokalnych (Dz.U. z 2016 r., poz. 716).

Ustawa z dnia 15 listopada 1984 r. o podatku rolnym (Dz. U. z 2015 r. poz. 1045). 